THE NORWEGIAN-BRITISH-SWEDISH ANTARCTIC EXPEDITION, I 949-52 289

improvement which takes the form of higher temperatures especially in winter, spring, and autumn. The ablation season has been lengthened to such a degree that the total amount of ablation more than compensates for the small increase in the precipitation of snow and hoar frost. One speaks of increased atmospheric circulation accelerating the transfer of heat from low to high latitudes. The present climatic fluctuation is undoubtedly the most remarkable that has occurred for the last two hundred years, and is moreover a phenomenon of great economic significance, not least to the countries of the north. It is accordingly attracting the increasing interest of meteorologists, glaciologists and biologists. The problem cannot be discussed in its entirety until we know whether this climatic fluctuation extends also to the Antarctic or not. If it does, the climatic change is global and its cause probably must be sought outside the earth. If it does not, the perspective alters.

One consequence of the present glacier shrinkage is the rise in the levels of the oceans, calculated at about $\mathrm{I} \mathrm{mm}$. per annum. This relatively small figure indicates that the Antarctic and the bulk of the Greenland inland ice-which between them contain more than 90 per cent. of all the present-day ice covers-cannot have diminished at the same rate as the local glaciers. If the polar inland ice sheets should begin to melt as rapidly as the other glaciers, the rising sea-level would become a phenomenon of great and far-reaching practical importance. The whole problem of eustatic movements - the rije and fall of the sea surfaces-must remain more or less unsolved as long as we do not know for certain whether, and to what extent, the Antarctic has contributed to these volumetric changes.

Every effort will also be made to record the meteorological and climatological observations necessary for a proper understanding of glaciological processes.

\title{
MEETING OF THE INTERNATIONAL COMMISSION ON SNOW AND GLACIERS, OSLO, I 948
}

Thrs meeting was held under the auspices of the International Union of Geodesy and Geophysics from 17 to 28 August. The opening General Assembly was attended by H.M. King Haakon and H.R.H. The Crown Prince of Norway.

Considering the lapse of time since the last meeting at Washington in 1939 and the fact that several prominent officials had died, a considerable amount of work was satisfactorily completed. Representatives from twenty countries attended the Commission meetings, those from the British Commonwealth being Messrs. J. M. Wordie, W. N. McClean, Professor G. Manley, Lieut.-Col. A. Croft and G. Seligman (Great Britain); Messrs. R. F. Legget, Lieut.-Col. P. D. Baird and G. J. Klein (Canada); Mr. L. Kent (South Africa); and Mr. S. K. Banerji (India).

Over fifty papers were read in full, in summary or by title. A list is given below.

Dr. J. E. Church resigned the Presidency of the Commission and Professor H. W:son Ahlmann was elected President for the present triennium. Mr. J. M. Wordie was elected Vice-president and Lieut.-Col. F. D. Baird has undertaken the post of Honorary Secretary in place of the late Mr. F. E. Matthes. The Commission's title was changed to the "International Commission on Snow and Ice"-a slightly more comprehensive if unnecessary variant.

It was decided to reduce the size of the Commission, which had become unduly large. In future each country adhering to the I.U.G.C. will be entitled to nominate one member and the President will be allowed to add ten more names to this number. It is recommended that a national group be formed in each country which would propose that country's representative. In Great Britain the British Glaciological Society could usefully continue to act in this capacity.

In view of their outstanding services to glaciology, Drs. P. L. Mercanton and J. E. Church were elected Permanent Honorary Members of the Commission. 
The next meeting will take place in Brussels in 1951 . The following questions have been set:

(a) The flow structure and mechanism of glacier ice.

(b) The basic physics of the snow cover.

(c) The conservation of snow for agricultural purposes.

Resolutions to the following effect were also passed:

(I) That the present Committee of Glacier Measurements should continue the yearly measurements of the length of the greatest possible number of glaciers and also enlarge its scope to include yearly threedimensional measurements on selected glaciers.

(2) That every effort should be made in the countries concerned to give the fullest possible information to the Danish Meteorological Office concerning the distribution of (Arctic) sea ice for its yearly reports.

(3) That attempts should be made to standardize a system of snow cover measurement. A Committee of three was set up to consider a suitable classification of snow : Messrs. V. J. Schaefer (United States), G. J. Klein (Canada) and M. de Quervain (Switzerland).

The organization at Oslo was in every way admirable and the delegates received many courtesies and were handsomely entertained. The handling of the Commission's meetings was in the capable hands of Professor Knut Faegri, whose good humour remained unruffled at all times.

It must, however, be said that the ceremonious formalities attending the meetings of such large bodies as the I.U.G.G. and its component Associations occupy valuable time. Of the twelve days of the meeting three and a half were originally alloted to the Commission on Snow and Glaciers, patently insufficient for the reading and discussion of over fifty papers. Extra meetings had therefore to be arranged. Even so in order to prevent their encroaching too much on the programmes of other Commissions within the Association of Hydrology (only one lecture theatre had originally been allotted for the whole Association) the entire snow and glacier programme became rushed. The reading of papers was hurried and the discussions suffered. The same thing happened at the Edinburgh meeting in 1936. It is now proposed that papers be pre-printed so that they may be studied beforehand, thus facilitating the discussions. But still more time should be given to the Commission if it is to do its work carefully and without haste. Six papers a day should be the very maximum.

The remedy would be to make the Commission autonomous within the Union. It would then be independent of the other Commissions and their affairs, which at present occupy a good deal of time. There is, with very few exceptions, a clear-cut boundary line between glaciology and the other studies in the Hydrologic Cycle-that is to say, the other studies of the Association of Hydrology. Neither body would suffer by the secession. The number of papers presented by the Commission probably exceeded those of all the other commissions put together and this forms an additional argument for a separate Association of Snow and Ice.

G. Seligman

\title{
PAPERS PRESENTED B Y \\ THE INTERNATIONAL COMMISSION ON SNOW AND GLACIERS, OSLO, I 948
}

\begin{abstract}
MSS., of these papers are in the possession of the British Glaciological Society and can be lent to members. Owing to shortage of time some papers were read by title only. Publication of all the papers will no doubt take place in due course.

Since many of the papers did not conform exactly with the original questions set at Washington in r939, the classification has been modified.
\end{abstract}

ICEBERGS AND RIVER ICE, ETC.

Keeping water from freezing by means of compressed air $t$

Supercooling and ice formation $t$

La genèse de la glace flottante et son apparition sur les cours d'eau de l'Europe centrale appartenant au Bassin Baltique $\dagger$
P. Kaitera
Finland
O. Devik
Norway
J. Lambor
Poland

† Joint meetings. 